\title{
Abortion in Northern Ireland: Has the Rubicon Been Crossed?
}

\section{Tom Frost $^{1}{ }^{10}$}

Published online: 23 June 2018

(C) The Author(s) 2018

\begin{abstract}
On 7 June 2018, the Supreme Court delivered their long anticipated ruling on whether the abortion laws in Northern Ireland are compatible with the European Convention on Human Rights. Although the case was dismissed on procedural grounds, a majority of the court held that, obiter, the current Northern Irish law was incompatible with the right to respect for private and family life, protected by Article 8 ECHR, "insofar as it prohibits abortion in cases of rape, incest and fatal foetal abnormality". This Supreme Court decision, seen alongside the May 2018 Irish referendum liberalising abortion, and the 5 June 2018 Parliamentary debate seeking to liberalise abortion laws in Northern Ireland and the rest of the UK, places renewed focus upon the abortion laws of Northern Ireland and Great Britain, which suggests that the 'halfway house' of the Abortion Act 1967 Act finally be close to being reformed to hand the decision of abortion to women themselves.
\end{abstract}

Keywords Abortion · UK Supreme Court · Northern Ireland · Abortion Act 1967

\section{Introduction}

There appears to be very little public and moral furore over the question of the legality of abortion in the United Kingdom compared to the position abortion takes in the public debate in, say, the United States of America. Yet despite this the legal position of abortion is markedly different in both countries. In the United States, there is a constitutional right to abortion. ${ }^{1}$ Contrastingly, in the United Kingdom abortion remains a criminal offence. Instead, abortion has been decriminalised in certain therapeutic situations and circumstances, as expounded by the Abortion Act $1967 .^{2}$

\footnotetext{
1 Roe v. Wade, 410 U.S. 113 (1973) (Supreme Court of the United States).

2 Abortion Act 1967 c.87 (Great Britain). The Act came into effect on 27 April 1968.

Tom Frost

T.M.Frost@sussex.ac.uk

1 School of Law, Politics and Sociology, Freeman Centre, University of Sussex,

Brighton BN1 9QE, UK
} 
However, the 1967 Act applies only to England, Wales and Scotland. It did not extend to Northern Ireland. Given the nature of the polity of the UK, there exist today three separate legal regimes for abortion-England and Wales, Scotland and Northern Ireland. Writing in 1985, Madeleine Simms argued that "the 1967 Abortion Act was a half-way house. It handed the abortion decision to the medical profession. The next stage is to hand this very personal decision to the woman herself" (Simms 1985: 94). Despite this, the half-way house remains the governing statute in Great Britain, and Northern Irish abortion law is still governed by a Victorian statute, the Offences Against the Person Act 1861 (OAPA).

Recent events, however, have placed renewed focus on Northern Irish abortion law. In February 2018, the UN Committee on the Elimination of Discrimination against Women (CEDAW) released a report stating that:

[T]housands of women and girls in Northern Ireland are subjected to grave and systematic violations of rights through being compelled to either travel outside Northern Ireland to procure a legal abortion or to carry their pregnancy to term (UN CEDAW 2018).

On 25 May 2018, Ireland held a referendum on the Thirty-Six Amendment to the Constitution Bill 2018, which completed its passage through the Oireachtas, the Parliament of Ireland, in March 2018. ${ }^{3}$ Under Articles 46 and 47 of the Irish Constitution the Constitution can be amended by way of a Bill which is passed by both houses of the Oireachtas, and then put to the Irish people in a referendum. ${ }^{4}$ If the referendum is successful then the Bill is signed into law by the Irish President. The referendum was successful in May, approved by $66.4 \%$ of voters (Referendum Ireland 2018). The Bill sought to replace Article 40.3.3 of the Irish Constitution, which reads:

The State acknowledges the right to life of the unborn and, with due regard to the equal right to life of the mother, guarantees in its laws to respect, and, as far as practicable, by its laws to defend and vindicate that right.

This subsection shall not limit freedom to travel between the State and another state.

This subsection shall not limit freedom to obtain or make available, in the State, subject to such conditions as may be laid down by law, information relating to services lawfully available in another state. ${ }^{5}$

The Bill replaces this section with the following words:

Provision may be made by law for the regulation of termination of pregnancy.

The passing of the May 2018 referendum meant that Northern Ireland will have the most restrictive abortion laws in the British Isles.

In part due to the Irish Referendum result, on 5 June 2018, the Labour MP Stella Creasy rose in the Commons Chamber to call for the repeal of the relevant sections

\footnotetext{
3 Thirty-sixth Amendment of the Constitution Bill 2018 (bill no. 29 of 2018).

${ }^{4}$ Constitution of Ireland, arts 46-47, available at http://www.irishstatutebook.ie/eli/cons/en/html (accessed 7 June 2018).

5 Constitution of Ireland, Article 40.3.3.
} 
of the OAPA across the United Kingdom, which make abortion a criminal offence. ${ }^{6}$ Such a repeal, if successful, would force both the Westminster Parliament and the Stormont Assembly in Belfast to legislate on the matter of abortion. Then, on 7 June 2018, the United Kingdom's Supreme Court dismissed an appeal from the Northern Ireland Human Rights Commission (NIHRC) challenging the legality of the abortion law in Northern Ireland, claiming that it was incompatible with Articles 3 and 8 of the European Convention of Human Rights (ECHR). ${ }^{7}$ The Supreme Court held by a majority of 4-3 that procedurally, the NIHRC did not have standing to bring proceedings and therefore the Supreme Court has no jurisdiction to make any substantive declaration. ${ }^{8}$

Despite this, however, on the substantive issues Lady Hale made clear that a majority (Lord Mance, Lord Kerr, Lord Wilson and Lady Hale) held that the current Northern Irish law was incompatible with the right to respect for private and family life, protected by Article $8 \mathrm{ECHR}$, "insofar as it prohibits abortion in cases of rape, incest and fatal foetal abnormality". ${ }^{9}$ Lady Black agreed with that holding in the case of fatal foetal abnormality. Lord Kerr and Lord Wilson also held that it is incompatible with the right not to be subjected to inhuman and degrading treatment, guaranteed by Article 3 ECHR. ${ }^{10}$ Lady Hale made clear that the "unusual circumstances" of this judgment, it was not possible to follow the Court's usual practice to identify a single lead judgment which represents the majority view. The Supreme Court decision, alongside the Parliamentary debate, places renewed focus upon the abortion laws of Northern Ireland, as well as those which apply to the rest of Great Britain, which suggests that the 'half-way house' of the 1967 Act may finally be close to being reformed to hand the decision of abortion to women themselves.

\section{The Current Law in the United Kingdom}

\section{The Offences Against the Person Act 1861}

Abortion remains a criminal offence in England, Wales and Northern Ireland by way of a Victorian statute, the Offences Against the Person Act 1861 (Sheldon 2016a, b: 334). ${ }^{11}$ As Sally Sheldon has noted, the OAPA was passed 20 years before married women were recognised as being able to own property in their own right, and 70 years before the achievement of equal women's suffrage (Sheldon 2016a:

\footnotetext{
6 Stella Creasy MP, HC Deb, 5 June 2018, vol 642, cols. 205-212.

7 In the matter of an application by the Northern Ireland Human Rights Commission for Judicial Review (Northern Ireland); Reference by the Court of Appeal in Northern Ireland pursuant to Paragraph 33 of Schedule 10 to the Northern Ireland Act 1998 (Abortion) [2018] UKSC 27 [1]-[3] (Lady Hale); Convention for the Protection of Human Rights and Fundamental Freedoms (adopted 4 November 1950, entered into force 3 September 1953) ETS 5; 213 UNTS 221, arts. 3 and 8.

8 [2018] UKSC 27 [3] (Lady Hale).

9 [2018] UKSC 27 [2] (Lady Hale).

10 [2018] UKSC 27 [2] (Lady Hale).

11 See $R$ (Smeaton) v Secretary of State for Health [2002] EWHC 610 (Admin) [332] (Munby J).
} 
334-335). The abortion offences in the OAPA are contained in sections 58, 59 and 60 :

s 58 - Every woman being with child, who, with intent to procure her own miscarriage shall unlawfully administer to herself any poison or other noxious thing, or shall unlawfully use any instrument or other means whatsoever with the like intent, and whosoever, with intent to procure the miscarriage of any woman, whether she be or be not with child, shall unlawfully administer to her or cause to be taken by her any poison or other noxious thing, or shall unlawfully use any instrument or other means whatsoever with the like intent, shall be guilty of an offence and being convicted thereof shall be liable to be kept in penal servitude for life.

s 59 - Whosoever shall unlawfully supply or procure any poison or other noxious thing, or any instrument or thing whatsoever, knowing that the same is intended to be unlawfully used or employed with intent to procure the miscarriage of any woman, whether she be or be not with child, shall be guilty of an offence, and being convicted thereof shall be liable to imprisonment for a term not exceeding five years.

s 60 - If any woman shall be delivered of a child, every person who shall, by any secret disposition of the dead body of the said child, whether such child died before, at, or after its birth, endeavour to conceal the birth thereof, shall be guilty of a misdemeanor, and being convicted thereof shall be liable, at the discretion of the court, to be imprisoned for any term not exceeding 2 years. $^{12}$

Sheldon, in analysing these sections, makes clear that the offences covered by the three sections are infrequently charged (Sheldon 2016a: 339-40). ${ }^{13}$ This infrequent use of these offences makes a 'strong case' for repeal in Sheldon's view, as in her view 'there appears no clear need to retain' the offences on the statute books (Sheldon 2016a: 339).

In addition these offences in the OAPA were passed without any Parliamentary debate, and without a debate outside of Parliament within the editorial columns of the Lancet and British Medical Journal (Sheldon 2016a: 338; Diggory and Peel 1977: 281-82). The 1861 Act carried forward those of an older statute, the Offences Against the Person Act $1837 .{ }^{14}$ Sheldon explains that the first legislative prohibition on abortion was passed in 1803 , which made a procurement of a miscarriage punishable by death if the woman was 'quick with child' or a 14-year prison term or

\footnotetext{
12 Offences Against the Person Act 1861, 24 and 25 Vict, ss.58-60 (UK).

13 Sheldon notes that in her analysis, "fewer than ten prosecutions per year under ss58 and 59" were made in England and Wales, and "only one conviction under s 60" was made in the 10 years prior to her article being published.

14 Offences Against the Person Act 1837, 7 Will.4 \& 1 Vict. c.85.
} 
transportation where she was not (Sheldon 2016a: 338; Blackstone 1979). ${ }^{15}$ Sheldon goes further, explaining that the 1861 provisions made no exception for therapeutic abortion (which was finally addressed by the 1939 case of $R v$ Bourne), ${ }^{16}$ and makes no distinction between abortions which occur early or late in pregnancy (Sheldon 2016a: 338-39). For Sheldon, this creates 'serious impediments' to the development and use of potentially beneficial treatments that operate soon after intercourse (Sheldon 2015).

The OAPA does not apply in Scotland, where abortion remains an offence at common law (Brown 2015: 30). ${ }^{17}$ Unlike the OAPA, the Scots common law recognised the lawfulness of therapeutic terminations (Brown, citing Baird 1975); Jonathan Brown argues that the dearth of case law in Scotland concerning abortion may be attributed to the fact that the legal profession was reluctant to interfere with decisions made by doctors (Brown 2015: 32). Brown makes clear that prior to the passage of the 1967 Act it was legally possible for a Scottish physician to carry out an abortion, meaning that Scotland, prior to 1967, had by far the most liberal abortion laws in the British Isles (Brown 2015: 33, citing Burnett 1811).

\section{The Infant Life Preservation Act 1929}

The Infant Life (Preservation) Act 1929 (ILPA), which applies in England and Wales, prohibits the intentional destruction of 'the life of a child capable of being born alive ... before it has an existence independent of its mother', unless this is done "in good faith for the purpose only of preserving the life of the mother". ${ }^{18}$ There is equivalent legislation in Northern Ireland. Section 25(1) of the Criminal Justice (Northern Ireland) Act 1945 states:

[A]ny person who, with intent to destroy the life of a child then capable of being born alive, by any wilful act causes a child to die before it has an existence independent of its mother, shall be guilty of felony, to wit, of child destruction ... Provided that no person shall be found guilty of an offence under this section unless it is proved that the act which caused the death of the child was not done in good faith for the purpose only of preserving the life of the mother. ${ }^{19}$

The 1929 Act does not apply in Scotland. Sheldon explains that an equivalent Act is necessary in Scotland as the High Court of Justiciary has inherent power to extend the scope of existing crimes to cover unusual situations and, possibly, to create new crimes' (Sheldon 2016a: 340n35; Norrie 1985). Sheldon makes clear that the statute was not intended to regulate abortions. Rather, it was designed to close a legal loophole whereby:

\footnotetext{
15 Quickening is the moment when the pregnant woman first feels the foetus moving inside her.

16 R Bourne (1939) $1 \mathrm{~KB} 687$ (CA).

17 Brown cites two cases as authority: John Fenton (1761) and Patrick Robertson and Marion Kempt (1627) Hume, I, 186.

18 Infant Life (Preservation) Act 1929, s.1(1).

19 Criminal Justice (Northern Ireland) Act 1945 c.15, s.25(1) (Northern Ireland).
} 
[S]omeone who killed a baby during the process of spontaneous birth would commit neither the offence of unlawful procurement of miscarriage nor murder, if the child did not yet have an existence independent of the mother and was thus not yet 'a person in being' (Sheldon 2016a: 340). ${ }^{20}$

The Act presumes that capacity for life is acquired at 28 weeks gestation. ${ }^{21}$ This presumption is rebuttable. The ILPA has been important for the role that it has played in the judicial interpretation of the OAPA. In Bourne, it was held that the word 'unlawfully' in section 58 of the OAPA presupposes the fact that in certain circumstances abortion must be lawful. The interpretation of the term was inferred from the exception contained in the ILPA - that a miscarriage was procured for the purpose of preserving the woman's life (Sheldon 2016a: 341). This law forms the basis of the abortion law in Northern Ireland. The Court of Appeal in Bourne made clear that a termination would be permitted if it preserved the life of the mother; Macnaghten $\mathrm{J}$ held that:

[I]f the doctor is of opinion, on reasonable grounds and with adequate knowledge, that the probable consequence of the continuance of the pregnancy will be to make the woman a physical and mental wreck, the jury are quite entitled to take the view that the doctor who, under those circumstances and in that honest belief, operates, is operating for the purpose of preserving the life of the mother. $^{22}$

Because of Bourne and the Criminal Justice (Northern Ireland) Act 1945, terminations in Northern Ireland are very rare. In 2016/17, there were only 13 terminations carried out in health and social care hospitals (Department of Health 2018). There were only 16 terminations in 2015/16 (Department of Health 2017), 16 in 2014/15 (Department of Health 2016), 23 in 2013/14 (Department of Health 2015), and 51 in 2012/13 (Department of Health 2014). As a result, many women travel from Northern Ireland to access abortion services in England and Wales. In 2017 there were 919 abortions performed for women from Northern Ireland in England and Wales. Whilst this is the highest level since 1991, numbers of Northern Ireland residents having an abortion in England and Wales has declined since a peak of 1855 in 1990 (Department of Health and Social Care 2018). As of 2017, these Northern Irish women are able to have abortions in Great Britain on the NHS, rather than having to pay the costs of a private abortion at a clinic.

Following an unsuccessful challenge to the policy which did not allow Northern Irish women to access abortions on the NHS in Great Britain, a challenge which ended up in the Supreme Court in June $2017,{ }^{23}$ Stella Creasy moved an amendment

\footnotetext{
${ }^{20}$ Lord Russell, HL Deb, 6 December 1928, vol. 72, col. 444.

21 Infant Life (Preservation) Act 1929, s.1(2) (England and Wales).

22 (1939) 1 KB 687, 694.

${ }^{23} R$ (on the application of $A$ and $B$ ) $v$ Secretary of State for Health [2017] UKSC 41 [20], [35] (Lord Wilson). The Supreme Court ruled by 3-2 that the difference of treatment between women in England and women in Northern Ireland regarding access to abortions on the NHS was justified given the 'democratic decision' of the people of Northern Ireland, through the Northern Ireland Assembly in Stormont, not to fund abortion services.
} 
to the Queen's Speech to allow for Northern Irish women to access NHS funded abortions in Great Britain (Elgot and McDonald 2017). In the end, this amendment was not necessary; due to the cross-party support for the amendment, including many Conservative MPs, the Government agreed to amend the Queen's Speech to extend funding for NHS abortions in Great Britain to women from Northern Ireland. ${ }^{24}$ Despite this shift, as Sally Sheldon pointed out in 2016, the status quo still means that Northern Irish women will have to arrange time off work or arrange childcare for a trip to Great Britain, putting legal abortion beyond the reach of many (Sheldon 2016a: 341-42). This in turn, Sheldon notes, leads to the increasing reliance on the purchase of abortifacient drugs on the internet. Although as Sheldon notes that such drugs may be cheaper than seeking an abortion in Great Britain, she argues that it leaves women 'to negotiate the risk of encountering unscrupulous traders who supply pills that are harmful or contain no active ingredients, or simply send nothing at all, leaving them now facing more advanced pregnancies' (Sheldon 2016a: 342; Conlon 2015). However, there is another risk-prosecution under s58 of the OAPA. There have been prosecutions under the OAPA for women (and men) in Northern Ireland procuring abortifacients such as Mifepristone and Misoprostol, which are considered 'noxious substances' that intend to procure a miscarriage (Belfast Telegraph Digital 2016; BBC News 2017a; BBC News 2017b), prosecutions which have been condemned by many across the Northern Ireland political spectrum, including Belfast City Council (McDonald 2018).

There is currently a pending judicial review case challenging a prosecution under s58 OAPA. The Public Prosecution Service in Northern Ireland charged a mother with procuring and supplying poison with the intent to cause a miscarriage in July 2013 (The Irish News 2017; BBC News 2017c). At the time, her daughter was aged 15 , and became pregnant as a result of a relationship with a 16-year-old boy. Lord Mance explained the detailed background further in his judgment.

The boy was abusive, and threatened to kick the baby out of her and to stab it if born. The daughter wanted to continue her schooling and go to university. Discussing the situation with her supportive mother, the daughter decided that she could not go through with the pregnancy or a termination in England. She would have had to obtain travel documents and go with her mother. Instead, she asked her mother to obtain pills to put an end to the pregnancy, neither apparently realising this was unlawful. Taking the pills led to heavy bleeding, as a result of which the daughter saw her GP, but not to termination of the pregnancy. The GP referred her to Children and Adolescent Mental Health Services ("CAMHS"), who advised a referral to a local maternity/gynaecologist clinic and also contacted Social Services, who a month later contacted the Police Service of Northern Ireland ("PSNI"). The PSNI then, without notice, obtained her medical records from her GP and CAMHS, which led to her being questioned on child protection grounds in her mother's absence, and

${ }^{24}$ Stella Creasy MP, HC Deb, 29 June 2017, vol. 626, cols. 847-851. 
then to her mother being interviewed under caution and charged by the Public Prosecution Service for Northern Ireland. ${ }^{25}$

The judicial review proceedings were heard in Belfast in the Autumn of 2017. The judgment, at the time of writing, is pending. Yet the case illustrates that despite the infrequent use of the OAPA, the effect of prosecutions still has a real impact on women in Northern Ireland today, creating a 'chilling effect' against abortions being provided in Northern Ireland. ${ }^{26}$

\section{Abortion Act 1967}

The Abortion Act 1967 created exceptions to the statutory abortion offences in England and Wales, and the common law offences in Scotland. It was not extended to Northern Ireland. There are four such exceptions, outlined in section 1 of the Act (as amended):

1. (1) Subject to the provisions of this section, a person shall not be guilty of an offence under the law relating to abortion when a pregnancy is terminated by a registered medical practitioner if two registered medical practitioners are of the opinion, formed in good faith-

(a) that the pregnancy has not exceeded its twenty-fourth week and that the continuance of the pregnancy would involve risk, greater than if the pregnancy were terminated, of injury to the physical or mental health of the pregnant woman or any existing children of her family; or

(b) that the termination is necessary to prevent grave permanent injury to the physical or mental health of the pregnant woman; or

(c) that the continuance of the pregnancy would involve risk to the life of the pregnant woman, greater than if the pregnancy were terminated; or

(d) that there is a substantial risk that if the child were born it would suffer from such physical or mental abnormalities as to be seriously handicapped. ${ }^{27}$

Section 1(2), as amended, makes clear that:

In determining whether the continuance of a pregnancy would involve such risk of injury to health as is mentioned in paragraph (a) or (b) of subsection (1) of this section, account may be taken of the pregnant woman's actual or reasonably foreseeable environment. ${ }^{28}$

Introduced as a Private Members' Bill by David Steel MP, the Abortion Act sought to put an end to back street illegal abortions, which placed women at serious risk

${ }^{25}$ [2018] UKSC 27 [89] (Lord Mance).

${ }^{26}$ [2018] UKSC 27 [176] (Lord Kerr).

27 Abortion Act 1967 c.87, s.1(1), as amended by the Human Fertilisation and Embryology Act 1990 c.37, s.37(1) (HFEA).

${ }^{28}$ Abortion Act 1967, s.1(2), as amended by HFEA 1990, s.37(2). 
of maternal mortality and morbidity, and to place doctors at the heart of providing abortions to women (Sheldon 2016b: 289).

Despite the Abortion Act, abortion remains a criminal offence due to the OAPA. In addition, women are barely mentioned in the Abortion Act. Instead, it is crafted in such a way to place medical professionals and their rights at the heart of the legislation. For instance, section 4 provides a right to conscientious objection so that healthcare professionals are not under any duty to perform abortions. ${ }^{29}$ Central to section 1(1) is the role of doctors. Section 1(1)(a) does create a broad area of clinical discretion (Sheldon 2016a: 343); such discretion is not unusual-in previous cases English courts have awarded professionals such as doctors a wide range of discretion to judge the competence of the actions of peers. ${ }^{30}$ This broad area of discretion was crafted deliberately; doctors were argued to be in the best position to determine when a termination was appropriate, or if necessary, to persuade and support a woman to maintain a pregnancy. ${ }^{31}$ The requirement for two medical professionals was intended as a check on rogue doctors (Sheldon 2016b: 289). The 1967 Act was never intended to allow for "abortion on request". ${ }^{32}$ It is correct that section 1(4) waives the requirement of seeking the approval of two medical practitioners where a doctor, in good faith, that a termination is immediately necessary to save the life or to prevent grave permanent injury to the physical or mental health of the pregnant woman. However, only 24 such abortions are reported to have been carried out in the 10 years prior to 2017 (Department of Health and Social Care 2018: 2.22).

It is also true that the 1967 Act is now dated, and in need of reform. Extending its provisions to Northern Ireland will not resolve the issues which relate to a 50-yearold piece of legislation not keeping up with medical innovations. In 1981, the House of Lords noted that the development of medical abortion 'invites, and indeed merits, the attention of Parliament'. ${ }^{33}$ Sheldon has explained that although s.1(1) states that an abortion must be carried out by a registered medical practitioner, today many of the methods for carrying out abortions can be conducted by nurses or midwives, and no longer require invasive surgical procedures as they once did (Sheldon 2016b: 300-307). The Courts have had to interpret the Abortion Act broadly to ensure these methods fall under its provisions. The Supreme Court, for instance, have interpreted that the statutory requirements are met:

\footnotetext{
29 Abortion Act 1967, s.4.

${ }^{30}$ See Bolam v Friern Health Management Committee [1957] 1 WLR 582 (QB); Bolitho v City and Hackney Health Authority [1998] AC 232 (HL). Most recently in 2015 the Supreme Court modified the Bolam and Bolitho tests to contend that doctors need to disclose risks which "a reasonable person in the patient's position" would be likely to attach significance to the risk: Montgomery $v$ Lanarkshire Health Board [2015] UKSC 11 [87\} (Lord Kerr and Lord Reed). Yet it is still a question of medical judgment as to when a doctor judges a reasonable patient would attach significance to any risk.

31 David Steel MP, HC Deb, 22 July 1966, vol. 732, col. 1076; David Steel MP, HC Deb, 13 July 1967, vol. 750 , col. 1348 .

32 David Steel MP, HC Deb, 22 July 1966, vol. 732, col. 1075.

33 Royal College of Nursing v Department of Health and Social Security [1981] 1 All ER 545, 566 (HL) (Lord Wilberforce).
} 
when [the abortion] was a team effort carried out under [the doctor's] direction, with the doctor performing those tasks that are reserved to a doctor and the nurses and others carrying out those tasks which they are qualified to perform. ${ }^{34}$

Numerous attempts to restrict the availability of abortion laws have been defeated over the years (Sheldon 2016b: 315, citing Keown 1988). Yet there also has been no opportunity to vote on liberalising the abortion laws since 1990 (Sheldon 2016b: 315; Sheldon 2009). Despite the flaws of the Abortion Act, Sheldon points out that the Act has de facto legalised abortion in Great Britain:

Modern abortion procedures are very considerably safer than carrying a pregnancy to term and thus in all cases there will be a basis for a doctor to reach a good faith determination that termination is indicated on the basis of the so-called 'statistical argument' that it would pose a lesser risk to a woman's health than would continuing the pregnancy. There is likewise a clear basis for an abortion to be authorised where two doctors form a good faith view that continuing an unwanted pregnancy is likely to pose a risk to a woman's mental health (Sheldon 2016a: 343).

And it is certainly true that the Act has made abortion much safer and more accessible than it was. As Diana Johnson MP stated in a debate in the House of Commons on the 50th Anniversary of the passing of the Abortion Act 1967:

We used to be a country where an estimated 87,000 to 100,000 illegal abortions took place every year and where unwanted pregnancies changed the lives of desperate women. Now, 200,000 women a year can access safe, free and legal services on the NHS. ${ }^{35}$

In $2017,98 \%$ of abortions $(185,448)$ were performed under section $1(1)(a)$, specifically that the pregnancy has not exceeded its twenty-fourth week and continuing the pregnancy would involve a risk of injury to the physical health of the pregnant woman (Department of Health and Social Care 2018: 2.14). 99.5\% of these abortions were performed because of a risk to the woman's mental health (Department of Health and Social Care 2018: 2.15). 1062 abortions were carried out under section 1(1)(a) under the requirement that if the pregnancy were to continue it would involve risk to the physical or mental health of the existing children of the family of the pregnant woman (Department of Health and Social Care 2018: 2.14). 3165 abortions were carried out under s.1(1)(d), and s.1(1)(b) and s.1(1)(c) only accounted for 176 abortions in 2017 (Department of Health and Social Care 2018: 2.14).

And it is also true that the abortion laws in Great Britain have been viewed by opponents of abortion (especially in Northern Ireland) not as creating exceptions to

\footnotetext{
34 Greater Glasgow Health Board (Appellant) v Doogan and another (Respondents) (Scotland) [2014] UKSC 68 [9] (Lady Hale).

35 Diana Johnson MP, HC Deb, 6 November 2017, vol. 630, col. 1302.
} 
the general illegality of abortion, but rather promoting 'abortion on demand'. Jim Shannon, a Democratic Unionist Party MP, made clear his views in the 2017 debate:

[A]t the same time we are meant to believe that abortion is somehow an expression of women's rights, but, on the contrary, some of us believe that it is so often the means by which vulnerable young women are themselves destroyed by the sorrow it can naturally engender. Even when abortion itself does not cause the destruction of women, their mistreatment by the industry that provides abortion daily in this country clearly can. ${ }^{36}$

It is with this background in mind that the Supreme Court decision of June 2018 was decided.

\section{The Legal Challenge to Northern Ireland Abortion Laws}

\section{Standing}

The NIHRC launched judicial review proceedings in Northern Ireland in December 2014, seeking a declaration under sections 4 and 6 of the Human Rights Act 1998 (HRA) that sections 58 and 59 of the OAPA 1861, and section 25 of the Criminal Justice (Northern Ireland) Act 1945 are incompatible with Articles 3, 8 and 14 of the ECHR, insofar as they relate to abortion access for women with pregnancies involving a 'serious malformation of the foetus or pregnancy as a result of rape or incest'. ${ }^{37}$ Section 4 of the HRA gives UK courts the power to declare primary legislation incompatible with the ECHR, although this does not affect the validity of primary legislation. Section 6 of the HRA makes it unlawful for a public authority to act in a way which is incompatible with a Convention right. Parliamentary Sovereignty and the nature of the HRA meant that the most the Supreme Court could do was issue a declaration of incompatibility stating that the Northern Irish law was incompatible with the ECHR ${ }^{38}$ Lady Hale made clear that the Supreme Court would not be able to "strike it down or interpret it out of existence". 39

The NIHRC were not seeking a judgment declaring that it was unlawful for Northern Ireland not to have an equivalent to section 1(1)(a) of the 1967 Act. However, they were seeking a declaration from the courts stating that women in Northern Ireland could lawfully access abortion services within Northern Ireland for cases of serious malformation of the foetus or pregnancy because of rape of incest. ${ }^{40}$

\footnotetext{
36 Jim Shannon MP, HC Deb, 6 November 2017, vol. 630, col. 1303.

37 [2018] UKSC 27 [43] (Lord Mance).

38 Human Rights Act 1998 c.42 s.4 (UK).

39 [2018] UKSC 27 [10] (Lady Hale).

40 Lord Mance did note that there is no longer any offence of 'incest'. Rather the relevant law is found in articles 32-36, 68-69 of the Sexual Offences (Northern Ireland) Order 2008, which mirror section 25-29 of the Sexual Offences Act 2003 which applies in England and Wales. See [2018] UKSC 27 [44] (Lord Mance).
} 
The first issue which the Supreme Court decided was that of standing. Did the NIHRC have standing to bring this challenge? Lady Hale noted that it would have been open to the NIHRC to support or intervene in proceedings brought by women who were directly impacted by the Northern Ireland abortion laws and wished to challenge them. ${ }^{41}$ On the issue of standing, a four-justice majority of the Supreme Court, comprising of Lord Mance, Lord Reed, Lady Black and Lord Lloyd-Jones, ruled that the NIHRC did not have the requisite standing to bring the legal challenge. ${ }^{42}$ The NIHRC was created by section 68 of the Northern Ireland Act 1998, and only has the powers which the statute confers upon it. ${ }^{43}$ The NIHRC relied upon section 69(5)(b) of the Northern Ireland Act 1998 for the authority to bring the proceedings. The relevant section states: 'The Commission may ... bring proceedings involving law or practice relating to the protection of human rights'. ${ }^{4}$

However, the Northern Ireland Act made clear that where the Commission intervenes in human rights proceedings, the person starting the proceedings must be an actual or potential victim of an unlawful act; where the Commission is starting human rights proceedings itself, there must be an actual or potential victim of an unlawful act to which the proceedings relate. ${ }^{45}$ For Lord Mance, there is no power in the Northern Ireland Act 1998 which confers a power on the NIHRC to institute or intervene in proceedings where the complaint relates only to the suggested incompatibility of primary legislation of the UK Parliament, rather than by pointing to an unlawful act or any actual or potential victim of it. ${ }^{46}$

A minority of the court concluded that the NIHRC did have standing to bring the proceedings. Lady Hale felt that the NIHRC had standing to bring proceedings under s.69(5)(b) of the Northern Ireland Act; s.71(2B) and (2C) do not limit the NIHRC's powers to challenge the compatibility of the Northern Ireland abortion laws with the ECHR. ${ }^{47}$ Lord Kerr similarly felt that the only restriction on the NIHRC's ability to challenge legislation was that the proceedings must involve a law or practice relating to human rights. ${ }^{48}$

\section{The Compatibility of the Northern Irish Law with the ECHR}

Given the Supreme Court's decision on the issue of standing, there could not have been any declaration of incompatibility made under the Human Rights Act 1998. However, all the judges engaged with the question of whether the abortion laws of Northern Ireland infringed the ECHR.

\footnotetext{
41 [2018] UKSC 27 [11] (Lady Hale).

42 [2018] UKSC 27 [42] (Lord Mance).

43 [2018] UKSC 27 [49] (Lord Mance), In re Northern Ireland Human Rights Commission [2002] NI 236 (HL).

44 Northern Ireland Act 1998, s.69(5)(b).

45 [2018] UKSC 27 [56] (Lord Mance) (pointing to sections 71(2B) and (2C) of the Northern Ireland Act 1998).

46 [2018] UKSC 27 [65], [70], [73] (Lord Mance).

47 [2018] UKSC 27 [17]-[18] (Lady Hale).

48 [2018] UKSC 27 [184] (Lord Kerr).
} 


\section{Article 3 ECHR}

Article 3 ECHR is an absolute right which prohibits torture and inhuman and degrading treatment or punishment. The European Court of Human Rights explained the concept in the case of Gäfgen in these terms:

In order for ill-treatment to fall within the scope of article 3, it must attain a minimum level of severity. The assessment of this minimum depends on all the circumstances of the case, such as the duration of the treatment, its physical or mental effects and, in some cases, the sex, age, and state of health of the victim. Further factors include the purpose for which the treatment was inflicted together with the intention or motivation behind it, as well as its context, such as an atmosphere of heightened tension and emotions. ${ }^{49}$

It was only a minority of the court, Lord Kerr and Lord Wilson, who held that the abortion laws in Northern Ireland violated Article 3 ECHR. In particular, Lord Kerr felt that degrading treatment involves subjecting someone to humiliation and debasement, and that:

In my view, it is plainly humiliating to require a girl or woman to continue a pregnancy when she knows that the foetus she carries will die or where she finds that pregnancy abhorrent because it is the consequence of rape or incest. $^{50}$

In Lord Kerr's judgment (with which Lord Wilson agreed), he contended that some women who are denied an abortion in cases of fatal foetal abnormality, rape, or incest will 'suffer psychological trauma'; this was enough for Lord Kerr to give rise to an Article 3 ECHR violation. In such circumstances, there is a positive duty on the state to protect individuals from the risk of a breach of Article 3 ECHR. ${ }^{51}$ Lady Hale, whilst expressing 'sympathy' for Lord Kerr's position, felt it was unnecessary for her to decide the point given that she concluded the Northern Ireland abortion laws violated Article 8 ECHR. ${ }^{52}$

However, a majority of the Supreme Court (Lord Mance, Lord Reed, Lady Black and Lord Lloyd-Jones) did not find that the Northern Ireland law was incompatible with Article 3 ECHR. Lord Mance contends that for there to be an Article 3 ECHR infringement, there needs to be a 'legally significant number of cases' where women denied an abortion will suffer so much that her Article 3 rights are violated. As this was not the case, Article 3 issues were not engaged by the case at hand. ${ }^{53}$ The minority and majority were also split on the issue of Northern Irish women having to travel to Great Britain and how this engaged with Article 3. On behalf of the majority, Lord Mance concluded that:

\footnotetext{
49 Gäfgen v Germany (2010) 52 EHRR 1, para 88 (European Court of Human Rights).

50 [2018] UKSC 27 [237] (Lord Kerr).

51 [2018] UKSC 27 [235] (Lord Kerr).

52 [2018] UKSC 27 [34] (Lady Hale).

53 [2018] UKSC 27 [82] (Lord Mance).
} 
[T]he current Northern Irish legislative position [does not involve] a breach of article 3 in respect of any pregnant woman faced with a choice between carrying her foetus to term or travelling abroad for an abortion ... it remains the case that the pregnant woman may, and it seems likely in most cases can if she chooses, travel elsewhere from Northern Ireland for an abortion. It is clear that this can be a distressing and expensive experience ... I do not see that current Northern Ireland law can be regarded as giving rise either generally or necessarily in any case to distress of such severity as to infringe article $3 \ldots{ }^{54}$

Lord Kerr, in disagreeing with the majority on Article 3, argued that women who must travel to Great Britain to access abortion services are subject to inhuman or degrading treatment:

Termination of pregnancy is one of life's most traumatic and fraught experiences. To be required to travel away from home and to undergo an abortion in unfamiliar surroundings without the normal support network that a woman would expect and hope to have is in itself deeply upsetting ... That distress can only be increased and compounded by forcing the woman to seek termination of her pregnancy in a different country, away from her family and friends and without the support of her own doctor. The fact of being required to do so is in itself sufficient to expose her to the risk of inhuman and degrading treatment. ${ }^{55}$

\section{Article 8 ECHR}

Lady Hale noted that it was 'common ground' for the Court that the current law is an interference with the right of pregnant women and girls to respect for their private lives which is guaranteed by Article $8(1)$ ECHR. ${ }^{56}$ The question for the Court was whether this interference is justified in terms of Article 8(2) ECHR, which allows for such interference if it is "in accordance with the law and is necessary in a democratic society ... for the protection of health or morals, or for the protection of the rights and freedoms of others'. 57

In assessing whether the interference is justified under Article 8(2) ECHR, the court sought to follow a four-stage process laid down in a 2012 case $^{58}$ If the interference is in accordance with the law, the next questions to ask are, first is the legislative objective sufficiently important to justify limiting a fundamental right?; second, are the measures which have been designed to meet it rationally connected to it?; third, are they no more than are necessary to accomplish it?; and finally, do they strike a fair balance between the rights of the individual and the interests of the community?

\footnotetext{
54 [2018] UKSC 27 [100] (Lord Mance).

55 [2018] UKSC 27 [238] (Lord Kerr).

56 [2018] UKSC 27 [19] (Lady Hale).

57 Article 8(2) ECHR.

${ }^{58} R$ (Aguilar Quila) v Secretary of State for the Home Department (AIRE Centre intervening) [2012] 1 AC 621 [45] (Lord Wilson).
} 
A majority of the Supreme Court accepted that the current law pursues the legitimate aim of a moral interest in protecting the life, health and welfare of the unborn child. ${ }^{59}$ For Lord Kerr:

If one posits that the legitimate aim is the protection of the unborn child, there is an obvious and rational connection between the aim and the restriction on termination of pregnancy. ${ }^{60}$

The key issue in this case and appeal was whether the Article 8 ECHR interference is necessary in a democratic society and whether it struck a fair balance between the rights of the pregnant woman and the interests of the foetus in maintaining the 1861 and 1945 Acts. ${ }^{61}$ In answering this question, the Court sought to distinguish the four circumstances of the challenge: fatal foetal abnormality, serious foetal abnormality, rape and incest.

\section{Serious Foetal Abnormality}

There was unanimity amongst the Justices that the prohibition of abortion in the case of serious foetal abnormality was not disproportionate and strike a fair balance between the rights of the woman and the community. Lord Mance argued that such a foetus had the potential to develop into a child, and a disabled child should be treated as having 'exactly the same worth in human terms as a non-disabled child'. ${ }^{6}$ Likewise, Lord Kerr was of the view that "many children born with disabilities, even grave disabilities, lead happy, fulfilled lives. In many instances they enrich and bring joy to their families and those who come into contact with them', and for these reasons he refuses to make a ruling that the law violated Article 8 ECHR. ${ }^{63}$ Lord Mance distinguished the Northern Ireland laws from the position of the Abortion Act, as although the 1967 Act distinguishes children who would be 'seriously handicapped' from others, 'this is in the context of a law which entrusts that judgment to the opinion of "two registered medical practitioners ... formed in good faith". The Northern Ireland legislation, which prohibits abortion of a foetus diagnosed as likely to be seriously disabled, cannot be said to be disproportionate. ${ }^{64}$

\section{Fatal Foetal Abnormality}

In the case of fatal foetal abnormality five Justices (Lady Hale, Lord Mance, Lord Kerr, Lord Wilson and Lady Black) were of the view that the abortion laws in Northern Ireland violated Article 8 ECHR. In such a case, there can be no community interest in obliging the woman to carry the pregnancy to term if she does not wish

\footnotetext{
59 [2018] UKSC 27 [21] (Lady Hale), [105] (Lord Mance), [278] (Lord Kerr).

60 [2018] UKSC 27 [279] (Lord Kerr).

61 [2018] UKSC 27 [21] (Lady Hale), [117] (Lord Mance), [287] (Lord Kerr).

62 [2018] UKSC 27 [133] (Lord Mance).

63 [2018] UKSC 27 [332] (Lord Kerr).

64 [2018] UKSC 27 [133] (Lord Mance).
} 
to do so, as there is no viable life to protect. The unborn foetus is not a person in law. ${ }^{65}$ The European Court of Human Rights were of the view that no single answer could be given to the question of when life begins and who is a person. ${ }^{66}$ Indeed, it 'was neither desirable nor possible to answer the question of whether the unborn was a person for the purposes of article 2 of the Convention'. ${ }^{67}$ In English law, the House of Lords have held that the foetus is 'neither a distinct person separate from its mother, nor merely an adjunct of the mother, but was a unique organism to which existing principles could not necessarily be applied' ${ }^{68}$

Lord Mance concluded in relation to fatal foetal abnormalities that '[i]t is difficult to see what can be said to justify inflicting on the woman the appalling prospect of having to carry a fatally doomed foetus to term, irrespective of such associated physical risk as that may on the evidence involve'. ${ }^{69}$ The effect of the law for Lord Mance is haphazard and disproportionate; it imposes on the 'well-informed' the stress, expense and inconvenience of having to travel for an abortion, whilst imposing life-time suffering on the most vulnerable who, through a lack of information and support 'are forced to carry their pregnancy to term' ${ }^{70}$ Lady Hale went further, outlining the practical complications involved in Northern Irish women travelling to Great Britain to access abortion services in the case of fatal foetal abnormality:

Travelling to Great Britain is even more difficult in such cases, as the problem is often detected comparatively late in the pregnancy, at 18-20 weeks, which leaves very little time to make the arrangements and there may be no counselling offered on what the options are. If the woman does manage to travel, not only will she have all the trauma and expense associated with that, but also serious problems in arranging the repatriation of the foetal remains. ${ }^{71}$

Supporting the majorities decision here was the knowledge that there is clear evidence that the views of the people of Northern Ireland (through opinion polls) that a majority support abortion in these circumstances. ${ }^{72}$

\section{Rape and Incest}

The Supreme Court was more divided on the questions of rape and incest. There is no one offence of 'incest' anymore, but the judges did use the term to cover the new offences created since $2003 .^{73}$ Lord Kerr went the furthest of all the Justices. He

\footnotetext{
65 In re MB (Medical Treatment) [1997] 2 FLR 426, 444 (emphasis added).

66 Vo v France (2004) 40 EHRR 12 [82].

${ }^{67} A, B$ and $C$ v Ireland (2010) 53 EHRR 13 [222].

68 Attorney General's Reference (No 3 of 1994) [1998] AC 245.

69 [2018] UKSC 27 [123] (Lord Mance).

70 [2018] UKSC 27 [126] (Lord Mance).

71 [2018] UKSC 27 [28] (Lady Hale).

72 [2018] UKSC 27 [24] (Lady Hale), [110] (Lord Mance). See also [2018] UKSC 27 [371] (Lady Black).

73 [2018] UKSC 27 [44] (Lady Hale). Since 2008, the relevant law is found in articles 32-36 and 68-69 of the Sexual Offences (Northern Ireland) Order 2008 SI 2008/1769, mirroring Sects. 25 to 29 and 64-65 of the Sexual Offences Act 2003 c. 42.
} 
made clear that a fair balance was not struck between the rights of the mother and the interests of the community. For Lord Kerr, no account is currently taking of a woman's right to autonomy, yet severe criminal sanctions are applied to those who obtain an abortion in Northern Ireland, save a narrow exception in the OAPA and 1945 Act. ${ }^{74}$ He also questioned the clarity behind the 1939 decision of Bourne:

One might observe, however, that the formula used by Macnaghten J does not lend itself to ready, confident definition. What is meant by "a physical and mental wreck"? Would contemporary thinking on that term accord with what it was understood to mean in 1938? There must be some question, at least, therefore, as to whether the law is sufficiently clear and accessible to women seeking abortion in Northern Ireland and to those medical practitioners from whom abortions are sought. ${ }^{75}$

Lady Hale, contrarily, concluded that the current state of the law has been criticised for its lack of clarity it is 'no more uncertain' than other areas of the law. ${ }^{76}$

The majority of the Court were clear that situations of rape and incest are those where 'the autonomy rights of the pregnant woman should prevail over the community's interest in the continuation of the pregnancy'. ${ }^{77}$ In the case of rape, a woman is not just expected to carry the foetus to birth, but is also potentially responsible for the child once born; Lord Mance sees such a situation as one where 'the law should protect the abused woman, not perpetuate her suffering', and as a result the law is disproportionate in its effects. ${ }^{78}$ In the most typical cases abortion in cases of incest involve 'exploitative relationships with young or younger female relatives'. Again Lord Mance was clear:

The agony of having to carry a child to birth, and to have a potential responsibility for, and lifelong relationship with, the child thereafter, against the mother's will, cannot be justified. ${ }^{79}$

Lord Reed, Lord Lloyd-Jones and Lady Black held that a prohibition on abortion in the cases of rape and incest did not infringe Article 8 ECHR. They relied on the European Court of Human Rights (ECtHR) decision of $A, B$ and $C$ v Ireland, which involved a challenge to the restrictions in Irish law on abortion. ${ }^{80}$ In $A, B$ and $C$ two women were seeking abortions on what were described as 'health and well-being grounds': the majority of the ECtHR found no violation. A third woman was concerned that continuing her pregnancy might endanger her life because she had cancer: the ECtHR found a violation of the State's positive obligation to secure effective respect for her private life because there was no accessible and effective procedure

\footnotetext{
74 [2018] UKSC 27 [326] (Lord Kerr).

75 [2018] UKSC 27 [269] (Lord Kerr).

76 [2018] UKSC 27 [20] (Lady Hale).

77 [2018] UKSC 27 [27] (Lady Hale).

78 [2018] UKSC 27 [127] (Lord Mance).

79 [2018] UKSC 27 [132] (Lord Mance).

${ }^{80}$ A, B and C v Ireland (2010) 53 EHRR 13 (European Court of Human Rights).
} 
by which she could have established whether she qualified for a lawful abortion in Ireland. ${ }^{81}$ However, the ECtHR relied on the possibility of Irish women being able to travel abroad for a reason for not condemning Irish law. Lord Reed and Lord Lloyd-Jones noted the similarly with $A, B$ and $C$ in that Northern Irish women are 'free to travel to England or Scotland' to have an abortion, leading them to conclude that the Article $8 \mathrm{ECHR}$ issues are not materially different from those considered by the ECtHR. ${ }^{82}$ Lady Black concluded that 'the balance between the protection of the life of the unborn child, the interests of society, and the rights of the pregnant woman may be struck in different ways'. ${ }^{83}$

\section{Institutional Competence}

The minority, Lord Reed, Lord Lloyd-Jones and Lady Black made clear that the issues of the appeal involved an 'abstract exercise'. There were no individual cases which need to be considered. Rather, the Supreme Court was invited to define categories of pregnancy in respect of which a termination must be legally available if the legislation is to be compatible with Article $8 .{ }^{84}$ Such a judgment would involve the court in deciding difficult issues, which involve 'highly sensitive and contentious questions of moral judgement', which should be settled by democratically elected and accountable institutions, not the courts. ${ }^{85}$ Lord Reed noted that a process of democratic consideration of these issues began in Northern Ireland yet was not completed due to the collapse of the devolved administration in January 2017. Yet for him a review of these issues should be completed, discussed and determined in 'a democratic forum, which is where they pre-eminently belong'. ${ }^{86}$ There was no need for the Supreme Court to 'pre-empt democratic debate', ${ }^{87}$ or come up with solutions which should be the result of democratic debate. ${ }^{88}$

The majority of the Court, conversely, disagreed with this view of this institutional competence. Lady Hale noted that Parliament, through section 4 of the HRA, had expressly granted to the courts the right to make a declaration on the compatibility of legislation with the ECHR ${ }^{89}$ In addition, all a declaration of incompatibility does is place the ball in Parliament's court. ${ }^{90}$ In addition, the Stormont Assembly is currently not in session. There is no 'assurance as to when or even that the Northern Ireland Assembly will resume its activity or address an issue on which it had wished to receive the working party report some 20 months ago'. ${ }^{91}$ As a result

\footnotetext{
81 [2018] UKSC 27 [23] (Lady Hale).

82 [2018] UKSC 27 [357] (Lord Reed).

${ }^{83}$ [2018] UKSC 27 [369] (Lady Black).

84 [2018] UKSC 27 [361] (Lord Reed).

85 [2018] UKSC 27 [362] (Lord Reed).

86 [2018] UKSC 27 [363] (Lord Reed).

87 [2018] UKSC 27 [364] (Lord Reed).

88 [2018] UKSC 27 [369] (Lady Black).

89 [2018] UKSC 27 [39] (Lady Hale).

90 [2018] UKSC 27 [40] (Lady Hale).

91 [2018] UKSC 27 [117] (Lord Mance).
} 
of this, Lord Kerr argues that the courts should not feel inhibited in ruling whether the current law offends Article 8 ECHR, as there is a complete absence of any views from the democratic institutions of Northern Ireland. ${ }^{92}$ Finally, in relation to the way forward, Lord Mance cautioned the Northern Ireland Assembly and the Westminster Parliament:

[T]he present law clearly needs radical reconsideration. Those responsible for ensuring the compatibility of Northern Ireland law with the Convention rights will no doubt recognise and take account of these conclusions, at as early a time as possible, by considering whether and how to amend the law, in the light of the ongoing suffering being caused by it as well as the likelihood that a victim of the existing law would have standing to pursue similar proceedings to reach similar conclusions and to obtain a declaration of incompatibility in relation to the 1861 Act. $^{93}$

\section{Conclusion}

The Supreme Court decision did not, on its face, provide relief to those women and campaigners who are seeking a change in the abortion laws in Northern Ireland. Yet has the Rubicon been crossed? Is reform to the UK's abortion laws now inevitable, and a question of if not when?

Despite the decision on the technicality of whether the NIHRC had standing, a four-to-three majority of the Court voiced their opinion that the abortion laws in Northern Ireland are in breach of Article 8 ECHR in cases of rape and incest, and a five-to-two majority held the laws were in breach of Article 8 ECHR in cases of fatal foetal abnormality. Commentators on the judgment made clear that it is important not to underestimate the significance of this ruling, as it is the first case considering Northern Irish abortion law in substantive terms, and the first identifying a human rights incompatibility (McNeilly, Bloomer, and Pearson 2018).

Seen in light of the 5 June 2018 debate in the House of Commons, there appears to be momentum for a change in the law. The Supreme Court have signalled their opinion (albeit obiter) that the abortion laws are in violation of Article 8 ECHR. After the judgment was announced on 7 June, a Northern Irish woman announced her intentions to launch a judicial review of the abortion laws of Northern Ireland after having had to travel to Great Britain for an abortion (Ferguson 2018). This challenge could resolve the technicality which led the Supreme Court to dismiss the challenge by the NIHRC; a challenge by a victim of the law could, given the tone of the judgment, be successful.

In addition, the political pressure is growing. Although the Secretary of State for Northern Ireland in the 5 June debate argued that abortion was a devolved matter

${ }_{92}^{22}$ [2018] UKSC 27 [295] (Lord Kerr).

93 [2018] UKSC 27 [135] (Lord Mance). 
for the Northern Ireland Assembly, ${ }^{94}$ the Equalities Minister, Penny Mordaunt MP, used Twitter after the debate to announce that: 'With authority comes responsibility. Message from NI Secretary of State today: NI should take that responsibility. Message from the House of Commons: if you don't, we will' (Mordaunt 2018). There is a clear majority of the House of Commons that seeks the liberalisation of abortion laws, which have always been voted on as a matter of conscience. ${ }^{95}$

However, what such a liberalisation will look like is not clear. Repealing sections 58 and 59 OAPA would go some of the way to liberalisation but doing so would require at the very least updating the Abortion Act 1967, as it was originally drafted as creating exceptions to the OAPA's criminal offences. Likewise, extending the Abortion Act to Northern Ireland would still leave the 1967 Act in need of updating, as well as leaving abortion as a criminal offence in the UK. Close attention will be paid to the introduction of the Domestic Abuse Bill to Parliament, which has not had a date set yet for its First Reading but proposals for a Bill have gone out for consultation in 2018 (Home Office and Ministry of Justice 2018). Stella Creasy, in wrapping up the 5 June debate, made clear that she wished to introduce amendments to the Bill when it is introduced to test the will of the House on that matter. ${ }^{96}$ Given the tumultuous events of May and June 2018, it appears that the UK's abortion laws will, at long last, soon be given the opportunity to be liberalised, even if the details of this are as yet unclear.

\section{Compliance with Ethical Standards}

Conflict of interest On behalf of all authors, the corresponding author states that there is no conflict of interest.

Open Access This article is distributed under the terms of the Creative Commons Attribution 4.0 International License (http://creativecommons.org/licenses/by/4.0/), which permits unrestricted use, distribution, and reproduction in any medium, provided you give appropriate credit to the original author(s) and the source, provide a link to the Creative Commons license, and indicate if changes were made.

\section{References}

Baird, Sir Dugald. 1975. Induced Abortion: Epidemiological Aspects. Journal of Medical Ethics 1: $122-126$.

BBC News. 2017a. Abortion pills: PSNI carry out searches and seizures. https://www.bbc.co.uk/news/ uk-northern-ireland-39255534. Accessed 10 June 2018.

BBC News. 2017b. Man and woman cautioned over abortion pills. https://www.bbc.co.uk/news/world -europe-38669974. Accessed 10 June 2018.

BBC News. 2017c. Appeal right granted in abortion pills case. https://www.bbc.co.uk/news/uk-northernireland-38759822. Accessed 10 June 2018.

Belfast Telegraph Digital. 2016. Belfast protest against prosecution of Northern Ireland woman who used abortion drugs held outside Public Prosecution Service. https://www.belfasttelegraph.co.uk/news/

\footnotetext{
94 Karen Bradley MP, HC Deb, 5 June 2018, vol. 642, col. 220.

95 Sir Peter Bottomley MP, HC Deb, 5 June 2018, vol. 642, col. 255

96 Stella Creasy MP, HC Deb, 5 June 2018, vol 642, col. 256.
} 
northern-ireland/belfast-protest-against-prosecution-of-northern-ireland-woman-who-used-abort ion-drugs-held-outside-public-prosecution-service-34607776.html. Accessed 10 June 2018.

Blackstone, William. 1979. Commentaries on the Laws of England. Chicago: University of Chicago Press.

Brown, Jonathan. 2015. Scotland and the Abortion Act 1967: Historical flaws, Contemporary Problems. Juridical Review 2: 29-50.

Burnett, John. 1811. A Treatise on Various Branches of the Criminal Law of Scotland. Edinburgh: Archibald Constable \& Co.

Conlon, Catherine. 2015. The Fragility of Respectability for Lone Mothers. In The Abortion Papers Ireland, vol. 2, ed. Aideen Quilty, Sinéad Kennedy, and Catherine Conlon, 228-243. Cork: Cork University Press.

Department of Health and Social Care. 2018. Abortion Statistics, England and Wales: 2017, Summary information from the abortion notification forms returned to the Chief Medical Officers of England and Wales. https://assets.publishing.service.gov.uk/government/uploads/system/uploads/attachment _data/file/714183/2017_Abortion_Statistics_Commentary.pdf2.57. Accessed 7 June 2018.

Department of Health. 2014. Northern Ireland Termination of Pregnancy Statistics 2012-13. https:// www.health-ni.gov.uk/sites/default/files/publications/dhssps/hs-termination-of-pregnancy-stats -2012-13.pdf. Accessed 7 June 2018.

Department of Health. 2015. Northern Ireland Termination of Pregnancy Statistics 2013-14. https:// www.health-ni.gov.uk/sites/default/files/publications/dhssps/hs-termination-of-pregnancy-stats-1314.pdf. Accessed 7 June 2018.

Department of Health. 2016. Northern Ireland Termination of Pregnancy Statistics 2014-15. https:// www.health-ni.gov.uk/sites/default/files/publications/dhssps/hs-termination-of-pregnancy-stats-1415.pdf. Accessed 7 June 2018.

Department of Health. 2017. Northern Ireland Termination of Pregnancy Statistics 2015-16. https:// www.health-ni.gov.uk/sites/default/files/publications/health/hs-termination-of-pregnancy-stats-1516.pdf. Accessed 7 June 2018.

Department of Health. 2018. Northern Ireland Termination of Pregnancy Statistics 2016-17. https:// www.health-ni.gov.uk/news/northern-ireland-termination-pregnancy-statistics-2016-17. Accessed 7 June 2018.

Elgot, Jessica and Henry McDonald. 2017. Northern Irish women win access to free abortions as May averts rebellion. The Guardian. https:/www.theguardian.com/world/2017/jun/29/rebel-tories-could -back-northern-ireland-abortion-amendment. Accessed 10 June 2018.

Ferguson, Amanda. 2018. Belfast woman to challenge NI abortion laws in High Court. The Irish Times. https://www.irishtimes.com/news/social-affairs/belfast-woman-to-challenge-ni-abortion-laws-inhigh-court-1.3522595\#.WxpA_1q51NU.twitter. Accessed 10 June 2018.

Home Office and Ministry of Justice. 2018. Government takes action to tackle domestic abuse. https:// www.gov.uk/government/news/government-takes-action-to-tackle-domestic-abuse. Accessed 10 June 2018.

Keown, John. 1988. Abortion, Doctors and the Law: Some Aspects of the Legal Regulation of Abortion in England from 1803 to 1982. Cambridge: Cambridge University Press.

McDonald, Henry. 2018. Belfast council passes abortion pills motion against prosecutions. The Guardian. https://www.theguardian.com/world/2018/apr/09/belfast-council-to-debate-abortion-pills-motio n-northern-ireland. Accessed 10 June 2018.

McNeilly, Kathryn Fiona Bloomer, and Claire Pierson. 2018. The Supreme Court's Decision on Northern Ireland's Abortion Law-What now?. http://blogs.lse.ac.uk/politicsandpolicy/supreme-court-on-niabortion-law/. Accessed 10 June 2018.

Mordaunt, Penny. 2018. https://twitter.com/PennyMordaunt/status/1004045245913296896. Accessed 10 June 2018.

Norrie, Kenneth. 1985. Abortion in Great Britain: One Act, Two Laws. Criminal Law Review: 475-488.

Potts, Malcolm, Peter Diggory, and John Peel. 1977. Abortion. Cambridge: Cambridge University Press.

Referendum Ireland. 2018. Referendum on the Thirty-sixth Amendment of the Constitution Bill 2018: Detailed Results. http://www.referendum.ie/detailed-results/?ref_id=12. Accessed 7 June 2018.

Sheldon, Sally. 2009. A Missed Opportunity to Reform an Outdated Piece of Legislation. Clinical Ethics 4: $3-5$.

Sheldon, Sally. 2015. The Regulatory Cliff Edge Between Contraception and Abortion: The Legal and Moral Significance of Implantation. Journal of Medical Ethics 41: 762-765. 
Sheldon, Sally. 2016a. British Abortion Law: Speaking from the Past to Govern the Future. Modern Law Review 79: 289-316.

Sheldon, Sally. 2016b. The Decriminalisation of Abortion: An Argument for Modernisation. Oxford Journal of Legal Studies 36: 334-365.

Simms, Madeleine. 1985. Legal Abortion in Great Britain. In The Sexual Politics of Reproduction, ed. Hilary Homans, 78-95. Gower: Aldershot.

The Irish News. 2017. Date set for landmark legal bid to stop prosecution of mother for allegedly procuring daughter's abortion. https://www.irishnews.com/news/northernirelandnews/2017/05/31/news/ date-set-for-landmark-legal-bid-to-stop-prosecution-of-mother-for-allegedly-procuring-daughter-sabortion-1041407/. Accessed 10 June 2018.

UN Committee on the Elimination of Discrimination against Women. 2018. Report of the inquiry concerning the United Kingdom of Great Britain and Northern Ireland under article 8 of the Optional Protocol to the Convention on the Elimination of All Forms of Discrimination against Women. http://tbinternet.ohchr.org/_layouts/treatybodyexternal/TBSearch.aspx?Lang=en\&Treat yID=3\&DocTypeCategoryID=7. Accessed 7 June 2018. 